\title{
Nondeformable Red Blood Cells Do Not Interfere with Uteroplacental Blood Flow in the Awake, Late-Pregnant Guinea Pig
}

\author{
CARLA M. VERKESTE, PETER F. BOEKKOOI, PRAMOD R. SAXENA, AND \\ LOUIS L. H. PEETERS \\ Department of Obstetrics and Gynecology, University of Limburg, $6202 \mathrm{AZ}$ \\ Maastricht [C.M.V., P.F.B., L.L.H.P.J and Department of Pharmacology, Erasmus University, 3000 DR \\ Rotterdam [P.R.S.], The Netherlands
}

\begin{abstract}
The fractional entrapment of rigidified [relative to control (labeled)] red cells after the intravascular bolus injection of a cocktail of these cells, and the concomitantly induced changes in cardiac output and its distribution (microspheres) were studied in 14 awake, late-pregnant guinea pigs. In a preceding validation study in eight nonpregnant guinea pigs, it was demonstrated that with this technique reproducible data could be generated on the fractional entrapment of rigidified red cells in all organs in this species except for lungs, liver, and spleen. In response to a bolus injection with rigidified and control red cells, only the brain showed preferential entrapment of rigidified red cells, together with a small but consistent increase in blood flow. In other organs (lungs, liver, and spleen excluded), neither preferential entrapment of rigidified red blood cells nor a consistent change in blood flow could be demonstrated. The results of our study suggest that circulating nondeformable red cells have no measurable adverse effect on the perfusion of the nondiseased hemochorial placenta in the awake, late-pregnant guinea pig. This does not exclude the possibility that rigidified red cells may increase the resistance to flow in a microcirculation that has been pathologically changed by some underlying disease. (Pediatr Res 29: 564-568, 1991)
\end{abstract}

\section{Abbreviations}

BV, blood volume

$\mathrm{CO}$, cardiac output $\left(\mathrm{mL} \cdot \mathrm{min}^{-1}\right)$

Hct, hematocrit (vol \%)

HR, heart rate

IUGR, intrauterine growth retardation

MAP, mean arterial pressure $(\mathrm{mm} \mathrm{Hg}$ )

RBC, red blood cell

$\mathrm{UBF}$, uteroplacental blood flow $\left(\mathrm{mL} \cdot \mathrm{min}^{-1}\right)$

The RBC membrane is a complex structure able to mold into a kaleidoscope of shapes in response to shear forces exerted on its surface. This property is referred to as RBC deformability and depends on the ratio between surface area and cell volume, the composition of the cell membrane, and the cytoplasmatic viscosity of the RBC. The deformability of the RBC serves the following functional purposes: 1 ) it reduces the resistance of RBC while they travel across both the macro- and microcirculation;

Received March 26, 1990; accepted January 14, 1991.

Correspondence: C. M. Verkeste, Department of Obstetrics and Gynecology, University of Limburg, P. O. Box 5800, 6202 AZ Maastricht, The Netherlands.
2) it improves the cell-to-wall contact in the capillaries, thus favoring gas exchange with the surrounding tissue; and 3) it reduces friction among $\mathrm{RBC}$ in flowing blood. The overall effect of these characteristics is a lower blood viscosity, particularly in high shear conditions.

The question as to how (human) pregnancy affects erythrocyte deformability is still unsettled, as indicated by reports claiming an unchanged $(1,2)$, an increased (3-7), or a decreased RBC deformability $(8,9)$ in the course of pregnancy. The controversy with respect to $\mathrm{RBC}$ deformability in normal pregnancy may be purely technical, being associated with its complex measurement and modest reproducibility. In pregnancies complicated by preeclampsia or IUGR, RBC deformability is diminished, thus contributing to the elevated whole blood viscosity in these conditions $(5,10,11)$. However, these studies do not elucidate whether the lower RBC deformability is a cause or an effect of the pregnancy complication for the following two reasons: 1 ) it is unknown whether RBC deformability decreases before, or in concert with, the development of fetal growth retardation/preeclampsia, and 2) the experimental data in the studies mentioned above are based on measurements in blood ex vivo and, thus, do not take into account the interaction between $\mathrm{RBC}$ deformability and pathologically changed placental microcirculation.

Assuming a cause and effect relationship, one could speculate that rigid erythrocytes encounter more resistance during their passage through the pores of the intervillous microarchitecture, thus giving rise to a higher overall resistance to flow. This phenomenon would be reflected in a higher placental entrapment of stiff $\mathrm{RBC}$ relative to normal $\mathrm{RBC}$, together with a reduced $\mathrm{UBF}$

The objective of our study was to determine in the awake, late-pregnant guinea pig: $l$ ) the ease of rigid, relative to control, RBC passage across the nonuterine capillary microcirculation and the effects of a bolus injection with rigidified and control $\mathrm{RBC}$ on $\mathrm{CO}$ and its distribution; and 2) the smoothness by which rigidified, relative to control, $\mathrm{RBC}$ travel across the porous placental microcirculation and the effect of a bolus injection with rigidified and control RBC on UBF. Before this study the methodology to measure fractional entrapment of differently labeled, manipulated $\mathrm{RBC}$ was validated in a group of nonpregnant guinea pigs.

\section{MATERIALS AND METHODS}

The study was performed in eight nonpregnant and 14 latepregnant albino guinea pigs with known postconceptional dates supplied by a commercial breeder (Winkelman, Borchen, Germany). Under general anesthesia and using aseptic techniques, polyethylene catheters (outer diameter, $0.96 \mathrm{~mm}$; inner diameter, $0.58 \mathrm{~mm}$ ) were inserted into the left ventricle, external jugular 
vein, and abdominal aorta as described in a previous report (12). In pregnant animals, the cannulation was performed around the 48 th day of gestation (term $=68 \mathrm{~d}$ ). All animals were allowed to recover from surgery for at least $6 \mathrm{~d}$.

Evaluation of label suitability. Eight nonpregnant guinea pigs were used to evaluate whether the injection of ${ }^{51} \mathrm{Cr}-$ and ${ }^{59} \mathrm{Fe}$ labeled RBC would result in a comparable fractional entrapment in the microcirculation. Such an observation would rule out methodologic error associated with type of radioactive label. The experiment was started by continuous monitoring of MAP and HR within the abdominal aorta (Statham pressure transducer) and measuring the arterial Hct (microcapillary method). After at least 15 min steady state in MAP and $\mathrm{HR}, \mathrm{CO}, \mathrm{CO}$ distribution, and the regional blood flows were determined with $15 \mu \mathrm{m}$ radioactive microspheres as follows (13): microspheres, labeled with either ${ }^{141} \mathrm{Ce}$ or ${ }^{103} \mathrm{Ru}$, were injected into the left ventricle over a period of $20 \mathrm{~s}$ while a reference sample was withdrawn from the abdominal aorta at a rate of $0.6 \mathrm{~mL} \cdot \mathrm{min}^{-1}$, from $10 \mathrm{~s}$ before injection until $30 \mathrm{~s}$ after flushing ( $1 \mathrm{~mL}$ saline). Immediately after flushing, a $10-\mathrm{mL}$ RBC suspension with a Hct adjusted to that of the recipient animal, prepared with blood from a nonpregnant donor guinea pig, was administered i.v. over a period of $5 \mathrm{~min}$. The RBC suspension was prepared as follows: Ten $\mathrm{mL}$ of blood from a donor guinea pig were centrifuged (3000 rpm, $10 \mathrm{~min}$ ), the supernatant was removed, and the RBC were resuspended in phosphate buffer for $30 \mathrm{~min}$ (14). After recovery of approximately $3.5 \mathrm{~mL}$ of $\mathrm{RBC}$ (recentrifugation), the $\mathrm{RBC}$ were divided into two equal batches, which were subsequently labeled with either ${ }^{51} \mathrm{Cr}\left(2.5 \mu \mathrm{Ci} \cdot \mathrm{mL}^{-1}\right)$ or ${ }^{59} \mathrm{Fe}(2.0 \mu \mathrm{Ci}$. $\mathrm{mL}^{-1}$ ), as detailed in the same report (14). Then, the suspension was recentrifuged and the supernatant removed and diluted in plasma to obtain the Hct of the recipient guinea pig. Three blood samples of $3 \mathrm{~mL}$ each were withdrawn from the abdominal aorta at 5,10 , and $15 \mathrm{~min}$ after the injection of the cocktail to determine the ${ }^{51} \mathrm{Cr} /{ }^{59} \mathrm{Fe}$ ratio in the circulating blood. Twenty min after the administration of the RBC suspension, $\mathrm{CO}$ and its distribution were remeasured using the microsphere with the other label.

Finally, the animals were killed by an overdose of pentobarbital, all organs were dissected, and the accumulated gamma radiation determined with a sodium crystal scintillation counter (Packard, Delft, The Netherlands). CO, CO distribution, and regional blood flows before and after the injection of the suspension were calculated as described previously (15). The fractional accumulation of ${ }^{51} \mathrm{Cr}$-labeled cells relative to that of ${ }^{59} \mathrm{Fe}$-labeled cells $\left(R_{\text {rcl }}\right)$ was calculated for each tissue using the following equation:

$$
\mathrm{R}_{\mathrm{rcl}}=\frac{\text { (Tissue activity }{ }^{51} \mathrm{Cr} / \text { activity }{ }^{51} \mathrm{Cr} \text { in blood sample) }}{\text { (Tissue activity }{ }^{59} \mathrm{Fe} / \text { activity }{ }^{59} \mathrm{Fe} \text { in blood sample) }}
$$

A $R_{\text {rel }}$ value equal to 1 indicates comparable accumulation of the differently labeled control RBC, whereas a value higher or lower than 1 indicates preferential trapping of ${ }^{51} \mathrm{Cr}$ - or ${ }^{59} \mathrm{Fe}$ labeled cells, respectively.

In each animal, the $\mathrm{BV}(\mathrm{mL})$ was estimated according to the equation:

$$
\mathrm{BV}+9=\frac{\text { Total injected activity }{ }^{51} \mathrm{Cr} \cdot \mathrm{wt} \text { blood sample }}{\text { Activity }{ }^{51} \mathrm{Cr} \text { in blood sample }}
$$

$\mathrm{RBC}$ trapping may be affected by the procedure used to kill the guinea pigs. To verify that our procedure involving the intraventricular injection of barbiturates did not invalidate the fractional entrapment of $\mathrm{RBC}$, the intravascular space in each organ $\left(\mathrm{mL} \cdot 100 \mathrm{~g}^{-1}\right)$ was estimated by using the information provided by the ${ }^{51} \mathrm{Cr}$-labeled control $\mathrm{RBC}$ and the estimated $\mathrm{BV}$ :
Tissue intravascular space $=$

$$
\frac{\text { Tissue activity }{ }^{51} \mathrm{Cr} \cdot \mathrm{BV} \cdot 100}{\text { Total injected activity }{ }^{51} \mathrm{Cr} \cdot \text { organ wt }}
$$

Deformability study. The subsequent study was performed in 14 guinea pigs that were 55 to $57 \mathrm{~d}$ pregnant (Table 1). The study protocol was identical to the one described above, except that the RBC suspension was treated differently: Half of the approximately $3.5 \mathrm{~mL}$ of donor $\mathrm{RBC}$ in the suspension were incubated in $0.025 \%$ glutaraldehyde diluted with phosphate buffer (rigidified) at $37^{\circ} \mathrm{C}$ for $30 \mathrm{~min}$ as described previously (14). The other half (control) was incubated in the phosphate buffer as described above. After incubation, both rigidified and control cells were labeled, centrifuged, and resuspended in plasma as described above. Details about the rigidification procedure are described elsewhere (14). The subsequent labeling was randomized: seven animals received a cocktail with ${ }^{51} \mathrm{Cr}$-labeled rigidified cells and ${ }^{59} \mathrm{Fe}$-labeled control cells, whereas in the other seven guinea pigs, the labels were reversed. The trapping of rigidified cells as fraction of control cells $\left(T_{\text {rel }}\right)$ for these animals was calculated by the following equation:

$$
\begin{aligned}
& \text { (Tissue activity hardened cells/ } \\
& \mathrm{T}_{\mathrm{rel}}=\frac{\text { activity hardened cells in blood sample) }}{\text { (Tissue activity control cells/ }}
\end{aligned}
$$

Statistics. Paired observations were analyzed with the Wilcoxon rank sign test. BV and intravascular space for each tissue in the nonpregnant group were compared with those in the latepregnant group using the Mann-Whitney test. A $p$ value less than $5 \%$ was considered significant. Results are expressed as mean \pm SD throughout the text.

\section{RESULTS}

Evaluation of label suitability. The relative distribution of ${ }^{51} \mathrm{Cr}$ and ${ }^{59} \mathrm{Fe}$-labeled control cells $\left(\mathrm{R}_{\mathrm{rcl}}\right)$, calculated for each tissue, are shown in Figure 1. The $\mathrm{R}_{\mathrm{rcl}}$ for lungs, liver, and spleen was lower than 1, indicating preferential accumulation of ${ }^{59} \mathrm{Fe}$ in these organs. It follows that the use of a $\mathrm{RBC}$ cocktail containing both ${ }^{59} \mathrm{Fe}$ - and ${ }^{51} \mathrm{Cr}$-labeled RBC is associated with preferential accumulation of the ${ }^{59} \mathrm{Fe}$-labeled $\mathrm{RBC}$ in these three organs. This resulted in a time-dependent increase in the ratio between ${ }^{51} \mathrm{Cr}$ and ${ }^{59} \mathrm{Fe}$ in the circulating blood, according to a complex, nonlinear function. Therefore, no information on $\mathrm{RBC}$ trapping in the lungs, liver, and spleen can be generated when ${ }^{51} \mathrm{Cr}$ and ${ }^{59} \mathrm{Fe}$ are used simultaneously. For all other organs, the type of label did not affect the trapping characteristics of the erythrocyte.

To determine whether the procedure used to kill the animals had affected the fractional distribution of $\mathrm{RBC}, \mathrm{BV}$ and tissue intravascular space were calculated for later comparison with reported data. The results of these calculations are listed in Tables 2 and 3. The values obtained were compared with those reported in the literature $(16,17)$. Although BV was higher in pregnancy, weight-specific $\mathrm{BV}$ did not differ between nonpregnant and latepregnant guinea pigs. Also, the intravascular space in each tissue did not differ between pregnant and nonpregnant guinea pigs.

Deformability study. Incubation of guinea pig RBC in glutaraldehyde completely rigidified the $\mathrm{RBC}$ membrane, as confirmed in vitro by ektacytometry (Technicon Instruments B.V., Gorin-

Table 1. Gestational age, maternal weight, litter size, total fetal weight, and total placental weight in 14 late-pregnant guinea pigs (mean $\pm S D)$

$\begin{array}{lc}\text { Gestational age }(\mathrm{d}) & 56 \pm 4 \\ \text { Maternal wt }(\mathrm{g}) & 992 \pm 155 \\ \text { Litter size }(n) & 3.7 \pm 1.3 \\ \text { Total fetal wt }(\mathrm{g}) & 217 \pm 76 \\ \text { Total placental wt }(\mathrm{g}) & 13.1 \pm 3.6\end{array}$




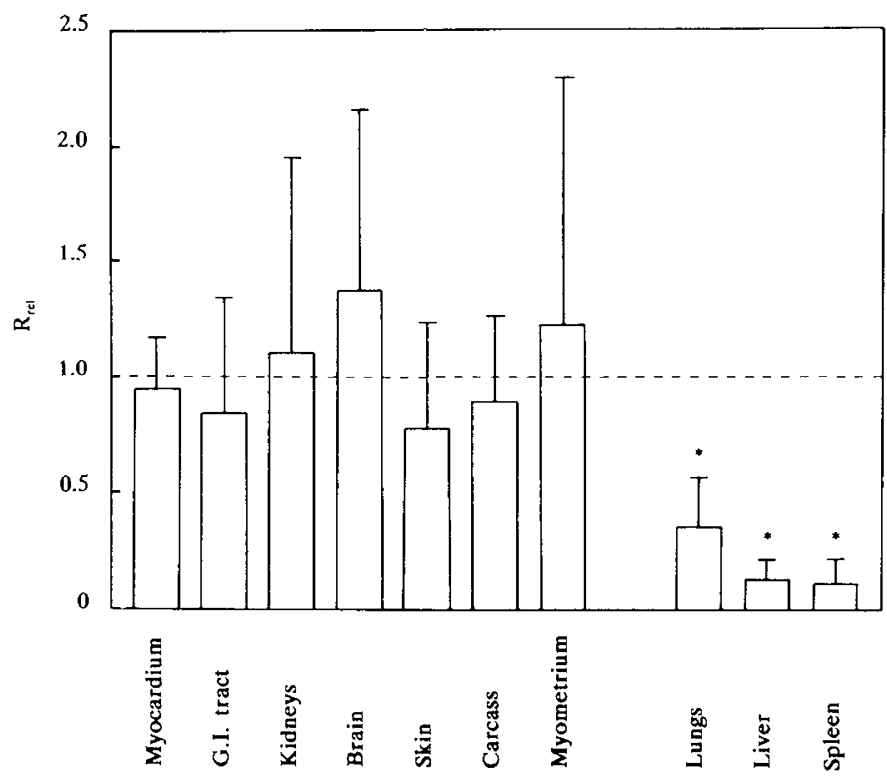

Fig, 1. Relative distribution of ${ }^{51} \mathrm{Cr}$ - and ${ }^{59} \mathrm{Fe}$-labeled red cells $\left(R_{r e l}\right)$ for each tissue in nonpregnant guinea pigs $(n=8)$. Statistical differences $(p<0.05)$ are indicated by an asterisk.

chem, The Netherlands) for shear rates between 10 and $255 \mathrm{~s}^{-1}$ (Fig. 2). After resuspension in plasma, the control and rigidified RBC were examined microscopically. All cells were intact and had a normal biconcave discoid shape. Macroscopic hemolysis was never observed. The ratio between hardened cells and control cells in the blood remained nearly constant throughout the experiments when the hardened cells were labeled with ${ }^{51} \mathrm{Cr}$ and the control cells with ${ }^{59} \mathrm{Fe}$. This indicated that both types of cells were removed from the systemic circulation at the same rate. In contrast, the latter ratio showed a time-dependent decrease when the hardened and control cells were labeled with ${ }^{59} \mathrm{Fe}$ and ${ }^{51} \mathrm{Cr}$, respectively.

The mean values for $T_{\text {rel }}$ calculated for all pregnant guinea pigs are illustrated in Figure 3. A value significantly higher than 1 for a certain tissue indicates that rigidified $\mathrm{RBC}$ are preferentially entrapped in the microcirculation of that tissue. This was only observed in the brain $\left(\mathrm{T}_{\text {rel }}=1.34 \pm 0.31\right)$. None of the other organs (excluding lungs, liver, and spleen), including the placenta, showed preferential accumulation of rigidified erythrocytes.
Reliable values for $\mathrm{CO}$ and organ flows could only be obtained in four animals due to problems with reference sampling. In these animals, values of $\mathrm{CO}$ before and 20 min after the bolus injection were almost identical $(210 \pm 37$ and $196 \pm 19 \mathrm{~mL}$. $\mathrm{min}^{-1}$, respectively) and comparable with values reported previously (13). The lack of a consistent change in HR (254 \pm 35 and $245 \pm 44 \mathrm{bpm}$, respectively) at stable MAP $(61 \pm 10$ and $61 \pm 9$ $\mathrm{mm} \mathrm{Hg}$, respectively) in all 14 guinea pigs also supports the concept that $\mathrm{CO}$ did not change consistently after the cocktail injection. Therefore, $\mathrm{CO}$ fractions rather than organ flows were compared. Figure 4 illustrates the distribution of $\mathrm{CO}$ in the pregnant animals before and $20 \mathrm{~min}$ after the injection of the blood suspension. The fraction of CO to brain $(1.88 \pm 0.61 \%)$ and that to the carcass $(29.41 \pm 13.88 \%)$ had increased after the injection ( $2.34 \pm 0.69$ and $35.14 \pm 15.82 \%$, respectively). On the other hand, no consistent change was noted in the $\mathrm{CO}$ fractions to any other organ, including that to the placenta.

\section{DISCUSSION}

Our study was designed to determine whether diminished RBC deformability interferes with the hemodynamic function in pregnancy in general and the perfusion of a hemochorial placenta in particular. The interest in the hemodynamic role of reduced RBC deformability was raised by clinical observations in IUGR and preeclampsia, where compromised UBF and diminished RBC deformability coincide. However, appropriate information on the role of $\mathrm{RBC}$ deformability in the microcirculation can only be obtained when the behavior of rigidified or otherwise manipulated $\mathrm{RBC}$ is studied in vivo in their normal rheologic interaction with the microcirculation. Theoretically, one would expect that in IUGR and/or preeclampsia all erythrocytes have a slightly reduced deformability. In that case, our technique would not be appropriate to evaluate the effect of decreased RBC deformability on UBF. However, recently it has been reported that in preeclampsia only a small fraction of RBC has lost its potency to deform (18). Therefore, the effect of RBC deformability on UBF and other flows was studied by evaluating the effects of a bolus injection with differently labeled rigidified and control RBC. Because the limitations of this technique are not well documented, we performed a validity study before the actual study. In doing so, it was observed that ${ }^{59} \mathrm{Fe}$-labeled, nonmanipulated RBC, which we planned to use in the actual study, became disproportionately entrapped in lungs, liver, and spleen. The type of label affected the sequestration of $\mathrm{RBC}$ as indicated by the differences in disappearance pattern of the ratio between

Table 2. Body and organ weight, baseline $\mathrm{CO}$ and $\mathrm{CO}$ distribution, ${ }^{51} \mathrm{Cr}$ distribution, and intravascular volume in each organ in the nonpregnant animals $(n=8)$

\begin{tabular}{|c|c|c|c|c|}
\hline & Weight $(\mathrm{g})$ & $\begin{array}{c}\mathrm{CO} \\
\left(\mathrm{mL} \cdot \mathrm{min}^{-1}\right)\end{array}$ & $\mathrm{BV}(\mathrm{mL})$ & $\begin{array}{l}\text { Weight-specific } \\
\text { BV }\left(\mathrm{mL} \cdot \mathrm{kg}^{-1}\right)\end{array}$ \\
\hline \multirow[t]{2}{*}{ Total body } & $544 \pm 163$ & $215 \pm 15$ & $39 \pm 4$ & $70 \pm 14$ \\
\hline & & $\begin{array}{c}\text { CO } \\
\text { distribution } \\
(\%)\end{array}$ & $\begin{array}{c}{ }^{51} \mathrm{Cr} \\
\text { distribution } \\
(\%)\end{array}$ & $\begin{array}{c}\text { Tissue } \\
\text { intravascular } \\
\text { space }(\%)\end{array}$ \\
\hline Myocardium & $2.1 \pm 0.3$ & $4.1 \pm 1.3$ & $0.4 \pm 0.2$ & $6.7 \pm 2.5$ \\
\hline Gastrointestinal tract & $45.1 \pm 9.5$ & $19.0 \pm 6.8$ & $2.9 \pm 2.1$ & $2.4 \pm 1.6$ \\
\hline Kidneys & $6.1 \pm 1.0$ & $12.0 \pm 4.8$ & $1.6 \pm 1.1$ & $10.7 \pm 4.3$ \\
\hline Brain & $3.8 \pm 0.3$ & $2.2 \pm 0.7$ & $0.1 \pm 0.1$ & $1.2 \pm 0.7$ \\
\hline Skin & $117 \pm 36$ & $7.3 \pm 2.0$ & $2.3 \pm 1.4$ & $0.9 \pm 0.8$ \\
\hline Carcass & $334 \pm 115$ & $43.8 \pm 11.4$ & $15.5 \pm 6.8$ & $2.1 \pm 1.3$ \\
\hline Myometrium & $1.3 \pm 0.5$ & $0.5 \pm 0.5$ & $0.2 \pm 0.1$ & $4.1 \pm 2.7$ \\
\hline Lungs* & $5.2 \pm 1.7$ & 100 & $2.3 \pm 2.3$ & $14.6 \pm 10.6$ \\
\hline Liver ${ }^{\dagger}$ & $25.8 \pm 5.4$ & $22.4 \pm 3.0$ & $6.7 \pm 4.9$ & $10.8 \pm 8.2$ \\
\hline Spleen & $1.3 \pm 0.6$ & $2.9 \pm 0.9$ & $0.9 \pm 0.7$ & $28.3 \pm 12.0$ \\
\hline
\end{tabular}

* Pulmonary perfusion is assumed to be equal to the CO.

† Hepatic perfusion is assumed to be equal to the sum of arterial hepatic and total splanchnic blood flow. 
Table 3. Body and organ weight, baseline cardiac output and cardiac output distribution, ${ }^{51} \mathrm{Cr}$ distribution, and intravascular volume in each organ in those pregnant animals that received ${ }^{51} \mathrm{Cr}$-labeled control red cells and ${ }^{59} \mathrm{Fe}$-labeled hardened red cells

\begin{tabular}{|c|c|c|c|c|}
\hline & Weight $(\mathrm{g})$ & $\begin{array}{c}\mathrm{CO} \\
\left(\mathrm{mL} \cdot \mathrm{min}^{-1}\right)\end{array}$ & $\begin{array}{c}\mathrm{BV} \\
(\mathrm{mL}) \\
\end{array}$ & $\begin{array}{l}\text { Weight-specific } \\
\mathrm{BV}^{*}\left(\mathrm{~mL} \cdot \mathrm{kg}^{-1}\right)\end{array}$ \\
\hline \multirow[t]{2}{*}{ Total body } & $1119 \pm 90$ & $212 \pm 49$ & $56 \pm 5$ & $75 \pm 8$ \\
\hline & & $\begin{array}{c}\text { CO } \\
\text { distribution } \\
(\%)\end{array}$ & $\begin{array}{c}{ }^{5} \mathrm{Cr} \\
\text { distribution } \\
(\%)\end{array}$ & $\begin{array}{c}\text { Tissue } \\
\text { intravascular } \\
\text { space }(\%)\end{array}$ \\
\hline Myocardium & $2.5 \pm 0.2$ & $1.8 \pm 1.1$ & $0.8 \pm 0.5$ & $17.1 \pm 11.1$ \\
\hline Gastrointestinal tract & $55.2 \pm 4.3$ & $20.3 \pm 4.6$ & $3.4 \pm 1.7$ & $3.5 \pm 1.8$ \\
\hline Kidneys & $7.2 \pm 0.5$ & $11.3 \pm 2.8$ & $1.5 \pm 0.7$ & $11.5 \pm 5.5$ \\
\hline Brain & $3.9 \pm 0.2$ & $1.5 \pm 0.5$ & $0.2 \pm 0.1$ & $2.7 \pm 1.7$ \\
\hline Skin & $143 \pm 11$ & $5.9 \pm 1.8$ & $3.0 \pm 1.8$ & $1.2 \pm 0.6$ \\
\hline Carcass & $411 \pm 24$ & $22.2 \pm 4.4$ & $11.1 \pm 1.4$ & $1.5 \pm 0.2$ \\
\hline Myometrium & $20.6 \pm 2.6$ & $2.0 \pm 0.8$ & $1.2 \pm 0.5$ & $3.8 \pm 0.7$ \\
\hline Placentas & $15.3 \pm 2.1$ & $13.0 \pm 6.3$ & $3.1 \pm 1.1$ & $11.7 \pm 5.1$ \\
\hline Lungst & $7.2 \pm 2.4$ & 100 & $5.6 \pm 2.9$ & $39.8 \pm 14.9$ \\
\hline Liverł & $31.1 \pm 2.8$ & $22.5 \pm 4.0$ & $3.5 \pm 0.3$ & $6.4 \pm 1.2$ \\
\hline Spleen & $1.4 \pm 0.2$ & $1.9 \pm 0.5$ & $1.2 \pm 0.3$ & $46.7 \pm 9.3$ \\
\hline
\end{tabular}

* Weight-specific BV is calculated as BV per unit nonuterine weight.

$\uparrow$ Pulmonary perfusion is assumed to be equal to the $\mathrm{CO}$.

$\ddagger$ Hepatic perfusion is assumed to be equal to the sum of arterial hepatic and total splanchnic blood flow.

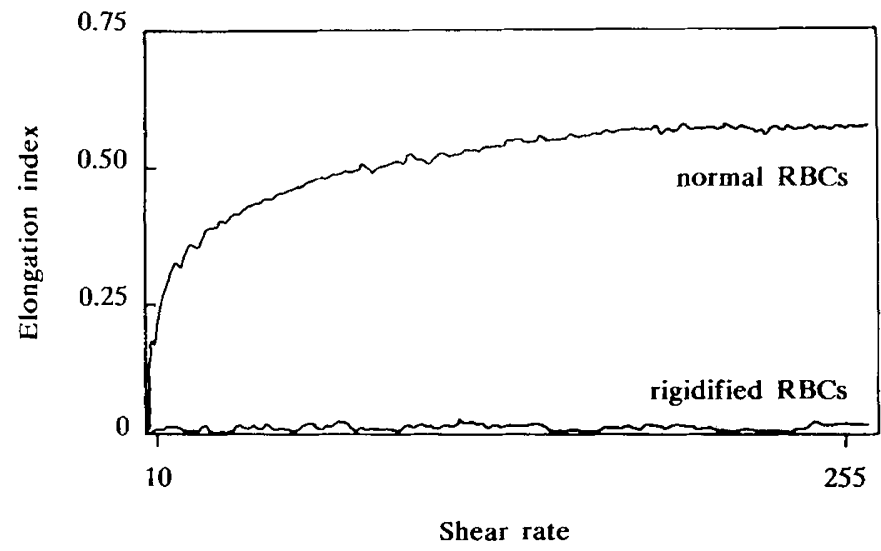

Fig. 2. Ektacytograms of control and rigidified guinea pig red cells at different shear rates $\left(\mathrm{s}^{-1}\right)$, depicted on one graph. The ektacytograms were obtained before injection of the cells into a recipient animal.

iron and chromium. This particular observation raises doubts about the physiologic meaning of the preferential trapping of hardened RBC in liver, spleen, and lungs previously reported using the same technique (14). One could speculate that accumulation of ${ }^{59} \mathrm{Fe}$-labeled $\mathrm{RBC}$, as well as rigidified $\mathrm{RBC}$ in lungs, liver, and spleen, may be a result of selective removal of these cells by macrophages of the reticuloendothelial system (19). Although we did not test the interchangeability of labels in pregnancy, we assumed that ${ }^{59} \mathrm{Fe}$-labeled $\mathrm{RBC}$ were not preferentially accumulated in the placenta because: $l$ ) the accumulation of ${ }^{59} \mathrm{Fe}$-labeled $\mathrm{RBC}$ appeared to be confined to reticuloendothelial system organs and 2) in the two groups of seven pregnant animals, rigidified and control RBC did not show disproportional accumulation of ${ }^{59} \mathrm{Fe}$-labeled $\mathrm{RBC}$ in the placentas.

$\mathrm{RBC}$ trapping data generated by this technique were used to calculate total BV and tissue intravascular space. Our values corresponded with those reported for BV and tissue intravascular space in the guinea pig (16), and were slightly higher and had a higher coefficient of variation than those found in the anesthetized mongrel dog (17); however, the relative distribution was almost identical. The latter indicates that our procedure used to

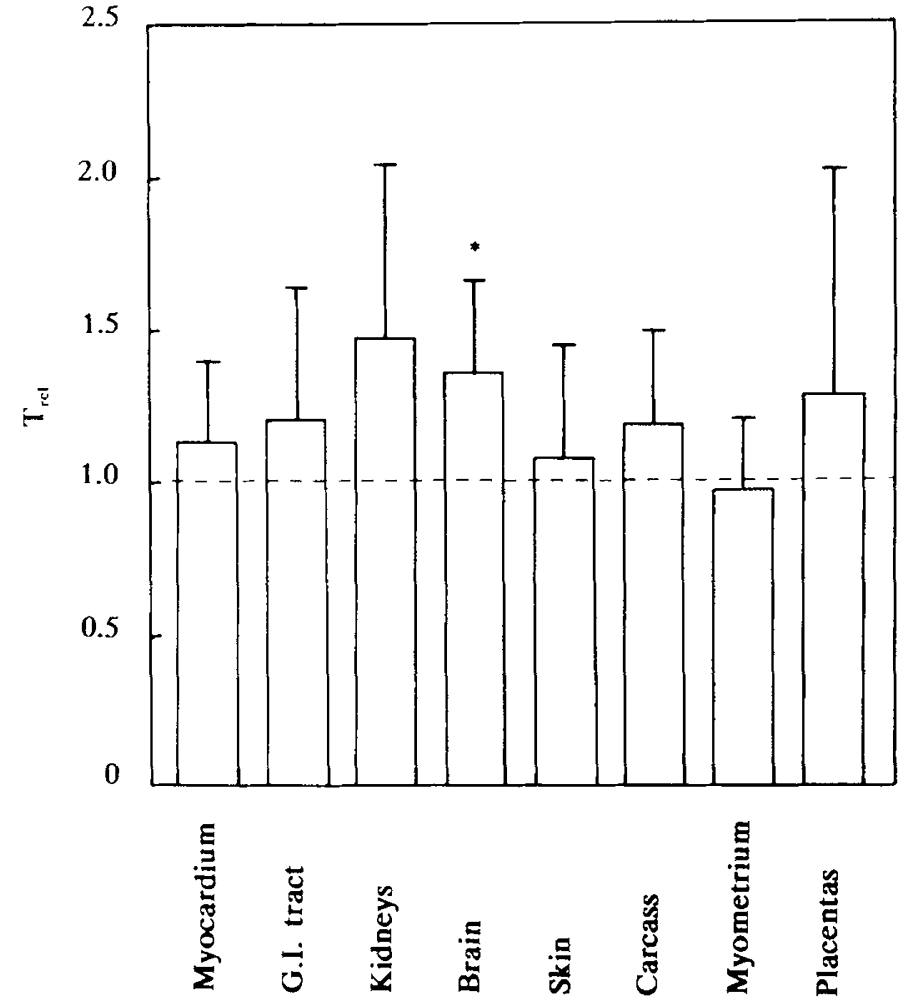

Fig. 3. Relative distribution of rigidified and control red cells $\left(T_{r c t}\right)$ for each tissue in pregnant guinea pigs $(n=14)$. Statistical differences $(p$ $<0.05)$ are indicated by an asterisk.

kill the guinea pigs did not distort the fractional distribution of $\mathrm{RBC}$ in the systemic microcirculation.

Total BV per unit weight was comparable in nonpregnant and pregnant animals. Also, the intravascular space of the peripheral organs did not differ between the nonpregnant and pregnant groups, although the lack of difference in this variable was partly related to the relatively large measurement error.

In our study, RBC were rigidified by incubating them in glutaraldehyde rather than in sulfhydryl reagents. It has been claimed that glutaraldehyde avoids not only the functional dam- 


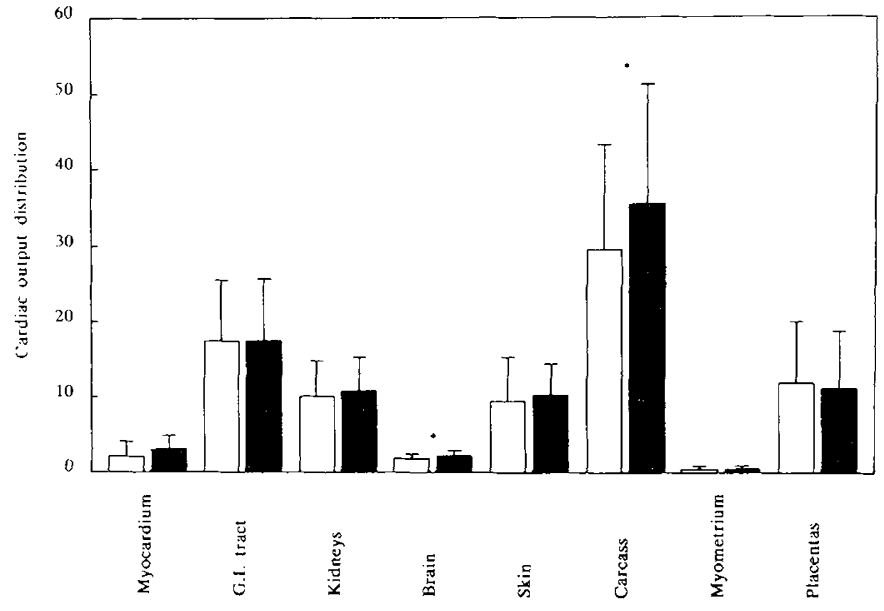

Fig. 4. Cardiac output distribution (1\%) to each tissue before (white bars) and $20 \mathrm{~min}$ after (black bars) injection of the red cell suspension in pregnant guinea pigs $(n=12)$. Statistical differences $(p<0.05)$ are indicated by an asterisk.

age induced by sulfhydryl reagents (19), but also osmotic swelling. The latter would have given rise to "physiological reactance" (20) by its associated method-related entrapment. The validation of our methodology did not include the evaluation of possible changes in erythrocyte function induced by the labeling procedure. This information was considered irrelevant in our study, inasmuch as we were only interested in the local rheologic aspects associated with $\mathrm{RBC}$ rigidification.

In the pregnant guinea pigs, a $T_{\mathrm{rcl}}$ of slightly higher than 1 was found for the brain, suggesting that rigidified $R B C$ become selectively entrapped in the cerebral microcirculation. Despite the presumably small biologic significance of this observation, one could speculate that the microcirculation of the brain with its end arterioles and lack of anastomoses is particularly prone to this type of embolization. It seems unlikely that the concomitant increase in cerebral blood flow is related to a diminished $\mathrm{O}_{2}$-carrying capacity because $\mathrm{O}_{2}$ and glutaraldehyde have different binding sites within the $\mathrm{Hb}$ molecule (21). However, the increase in cerebral blood flow may reflect impeded $\mathrm{O}_{2}$ diffusion due to diminished direct contact between RBC and endothelium. This would support the importance of the so-called "tank treading" of the deformable $\mathrm{RBC}$ in the release of $\mathrm{O}_{2}$ while travelling through the capillary bed. A lower diffusion of $\mathrm{O}_{2}$ to the tissue might have induced a secondary rise in cerebral blood flow.

In all other organs besides brain (lungs, liver, and spleen excluded), the $T_{\text {rel }}$ did not differ significantly from 1 , supporting the concept that a diminished RBC deformability does not increase the resistance of $\mathrm{RBC}$ to flow while travelling across the microcirculation.

Also for the uteroplacental vascular bed a $T_{\text {rel }}$ of about 1 was found, and the uteroplacental fraction of $\mathrm{CO}$ after injection of the blood suspension had not changed. Apparently, the ability of $\mathrm{RBC}$ to change their shape while squeezing themselves through the smallest pores in the microvasculature of the labyrinthine hemochorial placenta has little impact on the overall flowing properties in this tissue. Whether the human placental perfusion is also inert to a decrease in RBC deformability is obscure because I) the microarchitecture of the hemochorial human placenta differs from that in the guinea pig and 2) the simultaneous occurrence of impaired RBC deformability and compromised UBF coincides with pathologic changes in the placenta and in various other rheologically important variables such as Hct and fibrinogen.

We conclude from these results that in the awake, late-pregnant guinea pig, $\mathrm{RBC}$ deformability in this particular experimental setup does not influence placental perfusion or other organ flows, except for that of the brain.

\section{REFERENCES}

1. Inglis TCM, Stuart J, George AJ, Davies AJ 1982 Haemostatic and rheological changes in normal pregnancy and pre-eclampsia. Br J Haematol 50:461-465

2. Rodgers BD, Hreshchyshyn MM, Lee RV, Rodgers D, Ambrus CM 1988 Erythrocyte filterability in normal and high-risk pregnancy. Obstet Gynecol 71:192-197

3. Buchan PC, MacDonald HN 1981 Rheological studies in obstetrics and gynaecology. In: Buchan PC (ed) Clinical Aspects of Blood Viscosity and Cell Deformability. Heidelberg Press, New York, pp 175-190

4. Buchan PC 1980 Evaluation and modification of whole blood filtration in the measurement of erythrocyte deformability in pregnancy and the new born. Br J Haematol 45:97-105

5. Thornburn J, Drummond MM, Whigham KA, Lowe GDO, Forbes CD, Prentice CRM, Whitfield CR 1982 Blood viscosity and haemostatic factors in late pregnancy, pre-eclampsia and fetal growth retardation. $\mathrm{Br} J$ Obstet Gynaecol 89:117-122

6. Buchan PC 1984 Maternal and fetal blood viscosity throughout normal pregnancy. J Obstet Gynaecol (Bristol) 4:143-150

7. Mandelli B, Polatti F, Bolis PF 1985 Study of erythrocyte deformability in physiological pregnancy. Clin Exp Obstet Gynecol 12:16-20

8. Durocher JR, Weir MS, Lundblad EG, Patow WE, Conrad ME 1975 Effect of oral contraceptives and pregnancy on erythrocyte deformability and surface charge. Proc Soc Exp Biol Med 150:368-371

9. Kaibara M, Marumoto Y, Taniguchi I, Kigasawa K, Kobayashi T 1985 Erythrocyte filterability and adenosine triphosphate levels in normal pregnancy and puerperium. Int $J$ Microcirc Clin Exp 4:55-62

10. Buchan PC 1982 Preeclampsia-a hyperviscosity syndrome. Am J Obstet Gynecol 142:111-112

11. Gresele P, Guerciolini R, Nenci GG 1982 Erythrocyte deformability changes in normal pregnancy and pre-eclampsia. Br J Haematol 52:340-342

12. Peeters LLH, Mårtensson L, van Kreel BK, Wallenburg HCS 1984 Uterine arterial and venous concentration of glucose, lactate, ketones, free fatty acids and oxygen in the awake late pregnant guinea pig. Pediatr Res 18:11721175

13. Peeters LLH, Grutters G, Martin CB 1980 The distribution of cardiac output in the unstressed guinea pig. Am J Obstet Gynecol 138:1177-1184

14. Simchon S, Jan KM, Chien S 1987 Influence of reduced red cell deformability on regional blood flow. Am J Physiol 253:H898-H903

15. Saxena PR, Schamhardt HC, Forsyth RP, Loeve J 1980 Computer programs for the radioactive microsphere technique. Determination of regional blood flow and other hemodynamic variables in different experimental conditions. Comput Programs Biomed 12:63-84

16. Sisk BD 1976 Physiology. In: Wagner JE, Manning PJ (eds) Biology of the Guinea Pig Academic Press, New York, pp 63-98

17. Crystal GJ, Salem MR 1989 Blood volume and hematocrit in regional circulations during isovolemic hemodilution in dogs. Microvasc Res 37:237-240

18. Cunningham FG, Lowe T, Guss S, Mason R 1985 Erythrocyte morphology in women with severe preeclampsia and eclampsia. Am J Obstet Gynecol 153:358-363

19. Haest WM, Driessen GK, Kamp D, Heidtmann H, Fischer TM, Stöhr-Liesen M 1980 Is "deformability" a parameter for the rate of elimination of erythrocytes from the circulation? Pflugers Arch 388:69-73

20. Vatner SF, Braunwald E 1975 Cardiovascular control mechanisms in the conscious state. N Engl J Med 293:970-971

21. Corry WD, Meiselman HJ 1978 Modification of erythrocyte physicochemical properties by millimolar concentrations of glutaraldehyde. Blood Cells $4: 465-480$ 